\title{
COMMUNICATIVE IDENTIFIERS AS A MEANS OF CONSTRUCTING THE PROFILE OF A GIFTED SPEECH PERSON
}

\author{
Nikita I. Ilyukhin \\ Saratov State Academy of Law, Saratov, Russia \\ Svetlana Yu. Maksimova \\ Saratov State Academy of Law, Saratov, Russia \\ Kseniya V. Matsyupa \\ Saratov State Academy of Law, Saratov, Russia
}

\begin{abstract}
The article is devoted to communicative representation of a gifted speech person. It provides linguistic analysis of communicative behavior of some characters from modern movies in English with the aim to reconstruct their profiles by distinguishing a set of communicative identifiers. The authors estimate specificity in connections between the identifiers, the detail and the stage context as the most important tools for assembling the image of the character in a movie. It is stated that the main criterion is the repeatability of the element.The nature of the repeated elements and their significance in the process of character's image construction are defined, their classifications are proposed. It has been established that the communicative identifiers of a gifted speech person could be set as verbal and non-verbal (material) elements. The verbal identifiers are ranked by the nature of relationship between the repeating elements and the movie character and distributed into motivated (directly indicating the dominant feature of the gifted speech person), and unmotivated (connected with the characteristics of the gifted speech person indirectly) types.Non-verbal (material) identifiers are divided into general (characterizing a gifted speech person in general) and specific (describing a certain character) types.The functions of verbal and nonverbal identifiers have been stated as accumulating (the repeating element points to the main feature of the person's image), and mnemonic (the repeating element creates associative links with the character).
\end{abstract}

Key words: gifted person, speech person, gifted speech person, verbal identifier, non-verbal identifier, communicative behavior, repeatability.

Citation. Ilyukhin N.I., Maksimova S.Yu., Matsyupa K.V. Communicative Identifiers as a Means of Constructing the Profile of a Gifted Speech Person. Vestnik Volgogradskogo gosudarstvennogo universiteta. Seriya 2. त) Yazykoznanie [Science Journal of Volgograd State University. Linguistics], 2019, vol. 18, no. 4, pp. 186-199. ต่ (in Russian). DOI: https://doi.org/10.15688/jvolsu2.2019.4.14

\section{ИДЕНТИФИКАТОРЫ КАК СРЕДСТВО ФОРМИРОВАНИЯ ОБРАЗА ОДАРЕННОЙ РЕЧЕВОЙ ЛИЧНОСТИ}

\author{
Никита Игоревич Илюхин \\ Саратовская государственная юридическая академия, г. Саратов, Россия \\ Светлана Юрьевна Максимова \\ Саратовская государственная юридическая академия, г. Саратов, Россия \\ Ксения Владимировна Мацюпа \\ Саратовская государственная юридическая академия, г. Саратов, Россия
}


Аннотация. Статья посвящена изучению коммуникативной репрезентации одаренной речевой личности. На основе лингвистического анализа коммуникативного поведения персонажей современных англоязычных кинофильмов предложены критерии выделения ее коммуникативных идентификаторов. Определена специфика связи идентификаторов с деталью и сценическим контекстом как важнейшими инструментами создания образа персонажа в кинематографическом произведении. Показано, что основным критерием является повторяемость элемента. Охарактеризованы природа повторяющихся элементов и их значение в процессе построения образа персонажа. Установлено, что идентификаторами одаренной речевой личности могут быть вербальные и невербальные (вещественные) элементы. Предложены классификации повторяемых элементов. В зависимости от характера связи повторяющихся элементов с персонажем вербальные идентификаторы разделены на мотивированные (непосредственно указывающие на доминирующую черту одаренной речевой личности) и немотивированные (связанные с чертами одаренной речевой личности опосредованно). Вещественные идентификаторы разделены на общие (характеризующие одаренную речевую личность в целом) и конкретные (характеризующие того или иного персонажа). Выявлены функции вербальных и невербальных идентификаторов: аккумулирующая, при реализации которой повторяющийся элемент выражает главную черту образа личности, и мнемоническая, при реализации которой повторяющийся элемент создает ассоциативные связи с персонажем.

Ключевые слова: одаренная личность, речевая личность, одаренная речевая личность, вербальный идентификатор, невербальный идентификатор, коммуникативное поведение, повтор.

Цитирование. Илюхин Н. И., Максимова С. Ю., Мацюпа К. В. Идентификаторы как средство формирования образа одаренной речевой личности // Вестник Волгоградского государственного университета. Серия 2, Языкознание. -2019. - Т. 18, № 4. - C. 186-199. - DOI: https://doi.org/10.15688/jvolsu2.2019.4.14

\section{Введение}

Явление одаренности в настоящее время изучается в большей степени в психологии и психиатрии: психология рассматривает когнитивные способности одаренных детей и студентов, психиатрия пытается дать определение одаренности и выявить ее критерии [Mayer, 1999; Zeng, Proctor, Salvendy, 2011]. В языкознании же одаренная личность не изучается, хотя в последнее время именно одаренность становится объектом повышенного интереса в различных областях человеческой деятельности, особенно в искусстве. В кинематографе, например, набирает всю большую популярность тип личности, обладающей талантом в одной или нескольких сферах деятельности. Вслед за С. Кауфманом, мы понимаем одаренность как синтез интеллектуальных и креативных способностей человека [Kaufman et al., 2011].

Поскольку, как отмечают лингвисты, в «речи, насыщенной субъективным смысловым содержанием, отражается вся психология человека» [Киреева, 2014, с. 41], а сама речь - это «индивидуальный акт воли и разума» [Соссюр, 1999, с. 52], то рассмотрение одаренной личности в языкознании должно осуществляться через анализ ее коммуникативного поведения. В данном случае следует говорить об одаренной речевой, а не языковой личности, изучение которой акцентируется на исследовании ее интеллектуальных способностей [Караулов, 2010, с. 35]. На наш взгляд, при анализе коммуникативного поведения личности не менее важны и ее эмоциональные и экстралингвистические проявления. В связи с этим считаем целесообразным использование в исследовании термина «речевая личность». Вслед за В.В. Красных, полагаем, что речевая личность - это «личность, реализующая себя в коммуникации, выбирающая и осуществляющая ту или иную стратегию и тактику общения, выбирающая и использующая тот или иной репертуар средств (как собственно лингвистических, так и экстралингвистических)» [Красных, 2003, с. 51].

Коммуникативное поведение такой личности является разнообразным и изобилует как на вербальном, так и на невербальном уровне общения уникальными чертами, которые составляют психологический портрет одаренной речевой личности (далее - ОРЛ). Повторяющиеся элементы (детали) в речи, поведении и внешнем виде ОРЛ помогают сформировать ее образ, отразить ее тип и впоследствии образуют тесную взаимосвязь с персонажем.

Актуальность настоящей работы заключается в том, что впервые осуществлен ана- 
лиз коммуникативного поведения одаренной личности посредством исследования повторяющихся элементов (лингвистических и экстралингвистических), существующих в ситуациях речевого общения.

Цель исследования состоит в выявлении повторяющихся элементов, возникающих в процессе коммуникативного поведения одаренной речевой личности, и их систематизации.

Материалом для работы послужили современные англоязычные кинофильмы, главным героем в которых выступает личность, наделенная талантом в определенной сфере человеческой деятельности (Хэнк Муди, «Californication»; Коломбо, «Columbo»; Декстер, «Dexter»; Шон Mерфи, «Good Doctor»; Уилл Грэм, «Hannibal»; Г. Хayc, «House M.D.»; Лютер, «Luther»; Дэниел Дж. Пирс, «Perception»; Шерлок Холмс, «Sherlock»; братья Винчестер, «Supernatural»; Микки Холлер, «The Lincoln Lawyer»; Рэббит, «8 Mile»; Фрэнк Андерфуд, «House of Cards», Лайтман, «Lie to Ме»; У. Бишоп, «Fringe»; Уилл Хантинг, «Good, Will Hunting»; Шерлок Холмс, «Elementary»; A. Моцарт, «Amadeus», Патрик Джейн «Mentalist») ${ }^{1}$. Именно кинофильм позволяет объемно и детально исследовать коммуникативное поведение одаренной личности посредством анализа речи персонажа, его невербального поведения, экстралингвистических особенностей процесса коммуникации и сценического контекста.

Исследование проведено с применением описательного и сопоставительно-описательного методов, а также методики таксономического и количественного анализа речи персонажей кинофильма.

\section{Природа идентификаторов и их классификация}

Деталь наряду с конфликтом является важнейшим элементом в структуре кинофильма. Если конфликт возможно ассоциировать с двигателем сюжета, то деталь, наоборот, концентрирует в себе различные оттенки значений, смысловые коннотации, объединяя их в единый символ. Авторы кинопроизведения могут использовать детали по-разному: выдвигать их на первый план, персонифицировать их или структурировать через них сюжет.
Несмотря на различную природу рассматриваемых нами явлений, конфликт и деталь имеют тесную взаимосвязь, поскольку деталь может быть использована в качестве инструмента для создания конфликта, его развития или усугубления. Иными словами, деталь может непосредственно влиять на конфликт. По мнению М. Эпштейна, «конфликт может проявляться и несюжетно - в композиционном контрасте, противопоставлении отдельных ситуаций, предметных деталей, изобразительных ракурсов, в стилистической антитезе» [Эпштейн, 1987, с. 166].

Кроме того, деталь является распространенным и универсальным средством характеристики персонажа в художественном произведении (в том числе и кинофильме), поскольку, как считает И.В. Страхов, наделена «характерологической и композиционной функцией: способствует раскрытию образа персонажа, его духовного роста, созданию контрастного портрета и сопоставлению действующих лиц» [Страхов, 1998, с. 146]. Деталь, по мнению И.А. Щирова, сочетает в себе и форму, и содержание, а также воспроизводит в воспринимающем сознании чувственно конкретный и завершенный образ, компонентом которого является [Щирова, 2003, с. 17-18]. Она, как полагает Е.С. Добин, «стремится быть выделенной на первый план. Остановить читателя, приковать на миг всецело его внимание. Деталь тяготеет к единичности. Она заменяет ряд подробностей» [Добин, 1981, с. 307].

Мы полагаем, что идентификаторы можно охарактеризовать как детали образа одаренной речевой личности, поскольку они имеют идентичные с деталями характеристики: обладают значительной смысловой и эмоциональной силой и несут в себе, являясь частью образа персонажа, определенные коннотативные и денотативные значения об этом образе, обладая при этом самостоятельностью.

Условно идентификаторы можно разделить на два типа - речевые и неречевые идентификаторы.

Речевые, или лингвистические, идентификаторы. В речи любого человека есть повторяющиеся речевые элементы. Каждый рассмотренный нами персонаж повторяет определенные слова или словосочетания, которые не только являются элементами его ре- 
чевого портрета, но и акцентируют внимание зрителя на доминирующей или неярко выраженной черте героя. После определенного количества повторений речевая деталь образует ассоциативные связи с персонажем, становится его символом и может заменять собой различные элементы сценического пространства - человека, место, вещь, действие, повторяясь неоднократно на протяжении всей истории. Персонаж и символ представляют собой две взаимосвязанные системы одного целого.

Вещцественные, или экстралингвистические, идентификаторы тесно связаны со сценическим контекстом - совокупностью спецэффектов, настоящих или бутафорных бытовых предметов, находящихся в сцене кинофильма и взаимодействующих с героем в соответствии с режиссерским замыслом.

Авторы кинофильмов тщательно продумывают сценический контекст, расставляя предметы быта в кадре, подбирая свет, фон, большое внимание уделяя костюму персонажей, поскольку каждый предмет имеет определенное денотативное и коннотативное значения, которые могут повлиять на восприятие зрителем как отдельной сцены или персонажа, так и всего произведения.

Вещественные идентификаторы приобретают особое значение в процессе создания внешнего вида героя. Костюм героя представляет собой элементы одежды, в которых в высшей степени аккумулируется информация об образе и характере ее хозяина. «Деталь характера - это часть микроклимата, который повсюду окружает персонажа. Что угодно может стать такой деталью. Слишком короткие брюки, тесный или слишком широкий пиджак, шарф на шее» [Митта, 1999, с. 399]. «Костюм - это деталь характера, он участвует в конфликте. Потому что все, что мы делаем, подчинено одной цели - развить конфликты» [Митта, 1999, с. 400].

Несмотря на изменения в современном обществе: исчезновение ярко выраженной кастовости, стремление к упрощению и упразднению различий между людьми, - внешний вид людей по-прежнему влияет на первое впечатление о них. Костюм в качестве стилистического приема нередко играет определяющую роль в создании образа персонажа. Описывая данную особенность костюма, Г.Е. Крейдлин приводит цитату А.П. Чехова: «...для того, чтобы подчеркнуть бедность просительницы, не нужно тратить много слов, не нужно говорить о ее жалком несчастном виде, а следует только вскользь сказать, что она была в рыжей тальме» [Крейдлин, 2002, с. 21].

В кинофильме внешний вид персонажа играет одну из ключевых ролей, поскольку визуальные образы и детали здесь важнее и многограннее, чем в театре или в художественной прозе. «Невербальное выражение в кинотексте, в отличие от книги, обычно находят внешность, одежда, предметы быта; пейзаж, в том числе городской и фантастический, интерьер, средства передвижения; жест, мимика, пантомимика, проксемика. Фильм обращается к способности реципиента расшифровывать мир и людей, не прибегая к языку» [Слышкин, Ефремова, 2004, с. 42].

Мы выделяем 4 критерия определения идентификаторов ОРЛ:

1. Слово или вещь должны содержать в себе информацию об одной из особенностей речевой личности, то есть характеризоваться знаковостью.

2. Слово или вещь должны быть однозначными, то есть независимо от количества повторений и ситуации общения повторяемое слово или вещь должны выражать одно и то же значение.

3. Слово или вещь должны быть связаны с коммуникативным поведением речевой личности. При этом связь может быть прямая (использование слова в речи ОРЛ) или косвенная (например, упоминание о том или ином вещественном идентификаторе в ситуациях речевого общения главного героя ОРЛ - и других персонажей).

4. Слово или вещь должны повторяться. При этом количество повторений, необходимых для отнесения слова или вещи к идентификаторам, определяется индивидуально для каждой речевой личности. Если, например, персонаж появляется в своем «костюме»-идентификаторе в каждой сцене, то слово может повторяться в среднем 6-7 раз за весь сезон сериала («Hannibal»), 2 раза («House M.D.») или 3 раза («Sherlock») за серию.

Мы также полагаем, что использование идентификаторов не является уникальным и 


\section{МАТЕРИАЛЫ И СООБЩЕНИЯ}

характерным для коммуникативного поведения только ОРЛ приемом. Нам представляется, что идентификаторы могут быть использованы в речи любой речевой личности. В данной работе для нас важно то, как идентификаторы функционируют в речи ОРЛ, создают ее образ посредством своих основных функций.

\section{Речевые идентификаторы одаренной речевой личности}

Зафиксированные нами повторяемые слова и словосочетания условно можно разделить на 2 группы: мотивированные и немотивированные речевые идентификаторы.

Значениемотивированного идентификатора является прозрачным и концентрирует в себе одну из главных черт характера ОРЛ, проявляющуюся через другие языковые и неязыковые приемы [Илюхин, Максимова, Мацюпа, 2018]. Например, высокий уровень интеллекта одаренной личности аккумулируется в значении идентификатора, а также транслируется через использование комплексивов в процессе коммуникации ОРЛ с другими персонажами:

(1) H: - There's a reason that everybody lies, it works. It's what allows society to function. It's what separates man from beast. Lie is a tool. Lies are like children. Hard work, but they're worth it, because the future depends on them. / Люди лгут по определенным причинам. Только так функционирует общество. Именно ложь отличает человека от животного. Ложь - это инструмент. Ложь как дети: тяжело, но они того стоят, ведь они наше будущее.

- When you care about someone... / Когда любишь кого-то...

$\mathrm{H}$ : - You lie to them! You pretend that their constant ponderous musings are interesting. You tell them that they're not losing their boyish good looks or becoming worn out. / Ты ему лжешь! Делаешь вид, что его бесконечные скучные рассуждения тебе интересны и делаешь комплименты его молодой внешности (House M.D. It's a Wonderful Life);

(2) - You believe her over the patient himself. That's why we're taking this case. It's crazy, huh? What happened to "everybody lies"? / Вы верите ей больше, чем пациенту, поэтому мы взяли это дело. Это же безумие. А как же ваша фраза «все лгут»?

H: - I was lying. / Я солгал (House M.D. Honeymoon).
Встречающееся в приведенных контекстах слово lie, а также различные его производные являются речевым идентификатором такой ОРЛ, как доктор Грегори Хаус. Фраза everybody lies (все лгут) - лейтмотив коммуникативного поведения рассматриваемой ОРЛ (в среднем 3 использования за сезон) и становится визитной карточкой героя. Зритель начинает воспринимать данную реплику и героя как единое целое. Более того, фраза становится символом, который используется и в маркетинге (постеры, плакаты, трейлеры). Примечательно, что другие персонажи сериала также используют эту фразу или ссылаются на нее при общении с ОРЛ:

(3) - Until we figure out who's behind this, I'm sitting in with you guys. / Пока мы не выясним, кто стоит за всем этим, я буду здесь с вами.

- I am not the leak. / Я никому ничего не говорила.

- Somebody once told me that everybody lies. / Koе-кто однажды сказал мне, что все лгут (House M.D. Spin);

(4) [В палате больного, которому стало плохо.] H: - Oh. Let me have a look. / Дайте посмотреть.

[Осматривает его.]

- Of course, everybody lies, except a convicted murderer. / Ну конечно, все лгут, но только не осужденный убийца (House M.D. Acceptance).

Everybody lies (все лгут) является мотивированным идентификатором, поскольку несет информацию об одной из ключевых черт главного героя - негативном отношении к принятым в обществе нормам морали, а также открытом и демонстративном пренебрежении ими. Поведение героя на вербальном и невербальном уровнях пропитано критикой таких понятий и явлений, как добро, честность, уважение, такт и религия. Речевой идентификатор everybody lies (все лгут) выбран авторами неслучайно. Герой, будучи доктором, зачастую соприкасается с проявлениями лжи у пациентов, которая приводит к различным негативным последствиям и затрудняет процесс лечения больного.

Доктор Хаус часто повторяет слово boring (скучно) и однокорневые с ним слова. Эти единицы характеризуют коммуникативное поведение еще одной ОРЛ - Шерлока из телесериала «Sherlock». Поскольку данный речевой идентификатор отображает одинако- 
вые ключевые особенности этих героев, мы решили представить примеры его использования в одном ряду:

\section{Доктор Хаус:}

(5) $\mathrm{H}$ : - Chase, I want you there. I don't like reading surgeons' reports. They're boring. / Чейз. Я хочу, чтобы ты пошел туда. Я не люблю читать отчеты хирургов, это скучно (House M.D. Autopsy);

(6) H: - Immune reconstitution syndrome / Синдром восстановления иммунитета.

- His meds made him so much better, he made himself sick. Sounds pretty... / Его лекарства так хорошо подействовали, что ему стало хуже. Звучит очень...

$\mathrm{H}$ : - Boring! This is so not interesting. / Скучно! Это неинтересно (House M.D. Hunting);

(7) - Patient had an unexplained seizure. / У пациентки был необъяснимый припадок.

$\mathrm{H}$ : - Seizures are cool to watch, boring to diagnose. / Припадки круто наблюдать, но скучно диагностировать (House M.D. Forever);

(8) H: - So what was it? Infection? / Что это было? Инфекция?

- The surgery went fine. You've had no post-op... / Операция прошла хорошо, у вас нет постопер...

H: - Not me. Patient. Harpo. / Не у меня. У пациента. У Харпо.

- You just got shot, House. You should rest. / В вас только что стреляли, Хаус. Вам нужно отдыхать.

$\mathrm{H}$ : - I got shot. Diagnostically boring. Big fat tongue, on the other hand... endlessly entertaining. / В меня только что стреляли. Диагноз поставлен. Скучно. А вот большой толстый язык с другой стороны - очень интересно (House M.D. No Reason);

(9) H: - Well, if he's an old man, osteopenia would just be a fact of life. You make him comfortable, send him home, which means you're just boring me./ Итак, если он старик, то остеопороз - это всего лишь жизненный факт. Ты создаешь ему комфортные условия, потом отправляешь его домой, а это все скучно (House M.D. Sports Medicine);

(10) - We're discussing your new patient. / Мы обсуждаем твоего нового пациента.

H: - It must be a boring discussion. / Это будет очень скучное обсуждение (House M.D. Daddy's Boy).

\section{Sherlock:}

(11) - What's this all about, then? / Что здесь происходит?

SH: - Having fun. / Веселюсь.

- Fun? / Веселишься?

SH: - While I can. / Пока могу.

$-\mathrm{Mmm}-\mathrm{hmm}$. / Хм...

[Стук в дверь. В комнату заходит женщина.]

-Sherlock! / Шерлок!
SH: - Borgia Pearl. Boring, go. / Жемчужина Борджии. Скучно. Вон!

-But... / Нo...

SH: - Go! / Вон!

[Стук в дверь. В комнатузаходит глава полиции.]

SH: - Oh, this had better be good. / Надеюсь, это будет лучше.

- Oh, I think you'll like it. / Думаю, тебе понравится (Sherlock. The Six Thatchers);

(12) SH: - Get out! / Убирайтесь!

- She's possessed by the devil. I swear my wife is Channeling Satan! / Она одержима дьяволом. Я клянусь, она вызывала сатану!

SH: - Yes, boring, go away. / Конечно. Скучно. Убирайтесь.

- I'm not Channeling Satan. / Я не вызывала сатану.

SH: - Why not? Given your immediate alternative. / А зря. Прекрасная альтернатива (Sherlock. The Lying Detective);

(13) [Играют в шахматы, обсуждая дело.]

- All very interesting, Sherlock, but the terror alert has been raised to critical. / Это все очень интересно, Шерлок, но антитеррористические службы считают, что вероятность теракта высока.

- Boring. Your move. / Скучно. Твой ход (Sherlock. The Empty Hearse);

(14) [Ватсон стоит у окна и наблюдает за девушкой у двери на улице.]

- She's leaving. Oh, she's coming back. / Она уходит. О, нет. Она возвращается.

[Шерлок лежит на диване.]

SH: - She's a client, she's boring. I've seen those symptoms before. / Она клиент. Это скучно. Я уже видел подобные симптомы.

- Нmm? / Ммм?

SH: - Oscillation on the pavement always means there's a love affair. / Топтание на тротуаре всегда означает, что у нее интрижка (Sherlock. The Sign of Three);

(15) - Mr Holmes, I honestly think I had dinner with a ghost. Mr Holmes? With a ghost, Mr Holmes! / Мистер Холмс. Я серьезно думаю, что я ужинала с призраком. Мистер Холмс.

[Замечает, что Холмс спит. Повышает немного голос.]

- With a ghost, Mr Holmes! / С призраком, Мистер Холмс!

SH: - Boring, boring, boring. / Скучно. Скучно. Скучно (Sherlock. The Sign of Three);

(16) SH: - Dr. Mortimer wins. It's a childhood trauma masked by an invented memory. Boring. Goodbye, Mr Knight, thank you for smoking. / Доктор Мортимер права. Это все детская травма, замаскированная под воспоминание. Скучно. Всего доброго, Мистер Найт, спасибо, что покурили (Sherlock. The Hounds of Baskerville). 


\section{МАТЕРИАЛЫ И СООБЩЕНИЯ}

Рассмотренные речевые идентификаторы являются мотивированными. Одна из фундаментальных характеристик образа ОРЛ наличие высокого уровня интеллекта [Илюхин, 2015]. Эта особенность транслируется зрителю с первых сцен кинофильма с помощью различных инструментов (вербально и невербально). Речевой идентификатор boring (скучно) передает зрителю информацию о предельной рациональности мышления главного героя, нивелировании авторами в его сознании глубокой эмоциональной составляющей. Основную свою деятельность ОРЛ рассматривает как череду различных загадок и подходит к их решению со спортивным интересом, а не с желанием помочь больному или потерпевшему. Без основной деятельности, без решения головоломок, герой обезличивается.

Немотивированные речевые идентификаторы кодируют в себе информацию о черте или особенности образа ОРЛ, которая, на первый взгляд, не является доминирующей. Только периодичность использования и однозначное контекстуальное значение повторяемого слова (или словосочетания) во всех речевых ситуациях превращает его в речевой маркер, обладающий определенными сведениями о характере героя. Например:

(17) D: - Buried memory, forgotten all these years. It climbed inside me that day. And it's been with me ever since. My dark passenger. / Похороненное воспоминание, забытое все эти годы. Оно пробралось внутрь меня в тот день и было все это время. Мой темный попутчик (Dexter. Truth to be told);

(18) D: - Harry taught me to lie and keep my darkest secrets from those around me. / Гарри научил меня лгать и держать мои самые темные секреты подальше от окружающих (Dexter. The Dark Defender);

(19) D: - Now they're exposed to the glare, Reflecting my darkness like some grotesque carnival mirror. Harry was right. Nothing stays buried. Perhaps not even me. / Теперь они вставлены напоказ и отражают всю тьму внутри меня. Как какое-нибудь кривое зеркало на ярмарке. Гарри был прав. Все тайное становится явным. Возможно и моя история (Dexter. An Inconvenient Lie).

В приведенных примерах речевым идентификатором является слово dark (темный) и различные его производные, в которых основное контекстуальное значение идентифи- катора не изменяется. Повторяемое слово не имеет прямой связи с основными характеристиками ОРЛ: высоким уровнем интеллекта, креативными способностями, отношением к нормам морали и т. д. Речевой идентификатор содержит в себе значение, связанное с основной психической проблемой главного героя. Отметим, что некоторые исследователи доказывают наличие на генетическом уровне связи одаренности с некоторыми психическими патологиями [Keri, 2009; Kyaga et al., 2011; Shaner, Miller, Mintz, 2004].

Декстер Морган с детства, после того как у него на глазах была зверски убита его мать, болен шизофренией. Герой научился жить с болезнью, но она часто является причиной проблем в его жизни. Более того, шизофрения - причина многих конфликтов в произведении, основа характера и образа ОРЛ. Болезнь символизирует для ОРЛ все отрицательное, неконтролируемое в его сознании, поэтому герой использует слова и словосочетания dark (темный), darkness (темнота) или dark passenger (темный попутчик). К концу кинопроизведения зритель полностью отождествляет героя с речевым идентификатором, кодирующим его болезнь.

Речевой идентификатор, лишь косвенно связанный с талантом ОРЛ, использован и для создания образа Ганнибала в одноименном сериале:

(20) G: - I do not bind his arms or legs as I bury him in a shallow grave. He's alive. But he will never be conscious again. He won't know that he's dying. I don't need him to. This is my design. / Я не связываю его руки и ноги, пока закапываю его в могиле. Он жив, но он никогда не придет в себя. Он не узнает, что умирает, мне этого не нужно. Таков мой замысел (Hannibal. Amuse-Bouche);

(21) G: - I shoot Mr. Marlow twice, severing jugulars and carotids with near-surgical precision. He will die watching me take what is his away from him. This is my design. / Я дважды стреляю в мистера Марлоу, перерезая яремную артерию и сонные артерии с почти хирургической точностью. Он умрет, наблюдая за тем, как я все у него отнимаю. Таков мой замысел (Hannibal. Aperitif);

(22) G: - I made you pliable. Molded you. Set and sealed you where you lay. This is my design. / Я сделал вас пластичным. Слепил вас. Установил и запечатал вас там, где вы лежите. Таков мой замысел (Hannibal. Sakizuki). 
Ганнибал является талантливым сотрудником ФБР, он разработал собственный метод раскрытия самых опасных убийств. Он не собирает улики и не ищет свидетелей. У героя развита способность к эмпатии, поэтому он закрывает глаза и представляет себя на месте убийцы, налаживая с ним ментальную связь. Герой воспроизводит сцену убийства у себя в голове с доскональной точностью. Он ведет монолог от лица убийцы о совершенном преступлении, описывая каждую сцену вербально, таким образом приходя к пониманию мотивов преступника. Фраза this is my design (таков мой замысел) завершает каждый монолог Ганнибала и возвращает его в реальность. Данный эффективный метод работы отрицательно сказывается на психическом состоянии персонажа: он может подменять настоящую реальность выдуманной, продолжая находиться в роли убийцы. Речевой идентификатор приобретает символическое значение только после некоторого количества повторений.

Другим примером немотивированных идентификаторов может служить словосочетание my wife (моя жена), используемое в ситуациях речевого общения детективом Коломбо из одноименного телесериала:

(23) C: - I'm Lieutenant Columbo. I'm a fan of yours, a really big fan. In fact, I just got your latest album. / Я - лейтенант Коломбо. Ваш фанат, очень большой. У меня даже есть ваш последний альбом.

- Thank you. I didn't realize that you were interested in piano concertos. / Спасибо. Не думал, что вы любите концерты для фортепьяно.

C: - I'm talking about the Strauss waltzes "The Blue Danube", you know? / Мне больше по душе вальс Штрауса «На прекрасном голубом Дунае». Понимаете, о чем я?

-Yes. / Да.

C: - My wife and I, we both love it. / Моя жена и я очень любим это произведение.

- Thank you. That's very flattering of you. / Спасибо. Вы мне льстите (Columbo. Etude in Black);

(24) C: - Excuse me. I hope I didn't startle you, sir. One of your men said it was all right if I waited here. And I must say, it's been a real pleasure, because I've never seen so many beautiful flowers in my life. / Извините, я не хотел напугать вас. Один из ваших работников сказал, что я могу подождать вас здесь. Я должен сказать, это было истинное удовольствие, я никогда в жизни не видел столько прекрасных цветов.
- Orchids, Lieutenant. One of the finest collections in the country. / Орхидеи, лейтенант. Одна из лучших коллекций в стране.

C: - My wife loves African violets. / Моя жена обожает африканские фиалки (Columbo. The Greenhouse Jungle);

(25) - Lieutenant. I've got some guests waiting for me at home. / Лейтенант. Меня дома ждут гости.

C: - Oh, sorry, Doc. I got here as fast as I could. / Извините, док. Я постараюсь быстрее

- Where were you? On the golf course? / Где вы были? Играли в гольф?

C: - No. My wife went bowling, and I was sort of testing out this new hammock, listening to the game. / Нет. Моя жена пошла играть в боулинг, а я проверял новый гамак и слушал трансляцию игры (Columbo. The Most Crucial Game).

Речевой идентификатор my wife (моя жена) не связан ни с одной из основных черт характера персонажа. Более того, словосочетание $m y$ wife с каждым новым повторением нивелирует свое основное внеконтекстуальное значение для зрителя, который понимает, что герой использует данную фразу в качестве инструмента для установления контакта с подозреваемым. Таким образом он входит в доверие, его реплики становятся более тактичными, а настороженность собеседника исчезает. Фраза аккумулирует иное значение, характеризующее главного героя как человека рационального, наделенного интеллектом. Зритель никогда не увидит жену детектива. Возможно, ее просто не существует.

Периодически повторяясь в коммуникативном поведении ОРЛ, мотивированные и немотивированные речевые идентификаторы обладают 2 основными функциями: аккумулирующей и мнемонической. Аккумулирующая функция связана с тем, что повторяемое слово содержит информацию об одной из черт персонажа. Мнемоническая функция реализуется в создании неразрывной связи между повторяющимся словом или словосочетанием персонажем.

\section{Вещественные идентификаторы одаренной речевой личности}

Авторы кинопроизведений скрупулезно разрабатывают элементы внешнего вида героев, понимая, что даже незначительные неверно подобранные атрибуты внешнего вида 


\section{МАТЕРИАЛЫ И СООБЩЕНИЯ}

могут изменить какую-то главную черту характера героя, разрушив его образ.

Элементы внешнего вида вместе с другими предметами составляют сценический контекст и формируют коммуникативное пространство, в рамках которого проходит общение персонажей. Вещественные идентификаторы связаны с коммуникацией опосредованно: они упоминаются персонажами в ситуациях речевого общения и являются предметом разговора, в процессе или результате которого раскрывается черта личности, аккумулируемая идентификатором, они также могут быть типологической характеристикой персонажей, концентрируя характерные черты целой группы героев.

Анализируя экстралингвистические атрибуты поведения ОРЛ, мы можем выделить 2 типа вещественных идентификаторов: общие, выражающие признаки, свойственные всем ОРЛ, и конкретные, выражающие признаки, свойственные той или иной ОРЛ. В качестве общего идентификатора может выступать, например, внешний вид персонажа или его «костюм». По этому признаку ОРЛ можно разделить на «аристократов» и «бунтарей».

«Аристократы» тяготеют к строгому стилю в одежде, обладают ораторскими способностями и навыками речевого манипулирования. К «аристократам» можно отнести доктора Лайтмана («Lie to Me»), Патрика Джейна («Mentalist»), Шерлока Холмса («Sherlock»), Декстера Моргана («Dexter»). Они выбирают рубашки, свитеры нейтральных цветов, классические брюки и ботинки, реже джинсы и кроссовки. Последнее используется авторами кинофильма для того, чтобы герой был актуален и для молодого поколения, оставался модным и востребованным. На протяжении всего кинофильма герой, как правило, постоянен в выборе одежды, поэтому внешний вид становится визитной карточкой ОРЛ данного типа. «Аристократы» характеризуются предельной рациональностью мышления, пренебрежением эмоциями, достаточной сдержанностью в своем коммуникативном поведении и выборе костюма.

«Бунтари» не заботятся о своем внешнем виде. Они неряшливы, их одежда помята. Их костюм состоит из случайных элементов. У героев данного типа эмоции являются одной их ключевых характеристик образа. Коммуникативное поведение таких личностей характеризуется ярко выраженной вербальной эгоцентричностью и агрессией. Примерами подобных героев могут служить Моцарт (Amadeus), Грегори Хаус (House M.D.), Уолтер Бишоп (Fringe), Уилл Хантинг (Good, Will Hunting).

Конкретные вещественные идентификаторы представляют собой предмет, который периодически появляется на экране вместе с персонажем, взаимодействует с ним в рамках одного сценического контекста и несет определенную информацию о персонаже, раскрывая и дополняя его характер. Проанализировав 19 англоязычных кинопроизведений, мы выделили 19 вещественных идентификаторов. Их можно разделить на 3 группы: предметы одежды, автомобили и различные предметы быта, акцентирующие внимание на определенной черте ОРЛ. Наименее частотными в качестве идентификаторов являются предметы одежды (27 \%), более частотными - автомобили (33\%), самыми частотными - различные бытовые предметы (40\%). Рассмотрим каждую из групп подробнее.

Отдельные предметы внешнего вида, в отличие от костюма (стиля одежды) в целом, служат конкретными идентификаторами. На этих предметах сделан сценический акцент, они постоянно используются персонажами, приобретая, таким образом, статус самостоятельной детали. Примером таких идентификаторов может служить красный галстук старшего инспектора полиции Лютера («Luther»), который он всегда надевает на службу (вне ее герой предпочитает обычную одежду, не отличающую его от других персонажей). Постоянное использование красного галстука создает неразрывную связь между работой героя, его истинным характером и самой деталью. Так, в 5-м сезоне сериала по сюжету Лютер ведет отшельнический образ жизни, находясь в глубокой депрессии, и не работает в полиции. Внезапная новость об убийстве коллеги вынуждает его вернуться: у себя дома он подходит к стойке для одежды, срывает с нее покрывало, и зритель видит на вешалках несколько пиджаков и рубашек, а на отдельной вешалке крупным планом показаны красные галстуки. Зритель понимает, что «прежний» Лютер вернулся. 
К данной группе идентификаторов относятся такие предметы одежды, как пальто, шарфы, рубашки («Elementary», «Perception», «Fringe», «Sherlock», «Dexter»). Такой выбор вещественных идентификаторов обусловлен желанием авторов кинофильмов показать высокий уровень интеллекта главных героев. Все эти элементы внешнего вида имеют коннотативную связь с интеллигенцией - работниками умственного труда, обладающими образованием и широким спектром знаний, а интеллектуальные способности являются релевантной характеристикой коммуникативного поведения ОРЛ.

Автомобили уже давно проникли в нашу жизнь и стали неотъемлемой ее частью. Из средства передвижения автотранспорт перешел в сферу самовыражения и самоопределения. Неудивительно, что авторы кинофильмов выбирают в качестве конкретных вещественных идентификаторов именно автомобили. Чтобы подчеркнуть исключительность персонажа и противопоставить его другим героям кинофильма, авторы выбирают уникальные раритетные автомобили. Такой выбор продиктован необходимостью отображения изысканного вкуса, утонченности, романтизма, присущих ОРЛ. Зрителю имплицитно транслируется связь между высоким уровнем интеллекта и наличием раритетного, непопулярного, выделяющегося автомобиля. Такие транспортные средства передают не только общие характеристики образа ОРЛ, но и содержат в себе информацию о некоторых нюансах характера, о сфере деятельности персонажа. Например, брутальный, «маскулинный» автомобиль Chevrolet Impala 1967 г. выпуска является вещественным идентификатором братьев Винчестер («Supernatural»), основная деятельность которых - истребление нежити. Образ Хэнка Муди («Californication»), ветреного талантливого писателя, злоупотребляющего алкоголем и ведущего праздный образ жизни, неразрывно связан с элегантным, скоростным и легким Porshe 911. Импозантный, монументальный Lincoln Town Car, на номерах которого написано «NTGUILTY» (невиновен), принадлежит Микки Холеру («Тhe Lincoln Lawyer»), успешному и блестящему адвокату, и транслирует зрителю напористость характера, несгибаемость, а также вы- ступает символом процветания и той богатой и беззаботной жизни, к которой стремится его владелец.

Различные бытовые предметы характеризуются как самые частотные вещественные идентификаторы, поскольку не аккумулируют категориальные признаки ОРЛ, а связны с самим персонажем и его историей. Все идентификаторы данной группы являются конкретными.

Так, доктор Грегори Хаус на экране всегда появляется с тростью, потому что перенес операцию по удалению части бедренной мышцы и теперь хромает. Он вынужден всю оставшуюся жизнь терпеть боль и по этой причине пристрастился к викодину (болеутоляющему), частое применение которого привело к зависимости (Хаус даже проходил курс лечения в наркологической клинике). Доктору неоднократно советовали ампутировать ногу, но он не соглашался, считая, что это негативно скажется на его врачебной деятельности, которую он считает своим призванием, без которой не видит смысла жизни. Всю историю персонажа аккумулирует трость, ставшая партнером героя:

(26) - You know, there are other ways to manage pain. / Есть и другие способы справиться с болью.

H: - Like what? Laughter? Meditation? Got a guy, that can fix my third chakra? / Какие, например? Смех? Медитация? У тебя есть кто-нибудь, кто бы смог раскрыть мою третью чакру?

- You're addicted. / У тебя зависимость.

$\mathrm{H}$ : - If the pills ran my life, I would agree with you, but that's my leg, that's busy calendaring, what I can't do. / Если бы таблетки управляли моей жизнью, я бы согласился, но это нога постоянно контролирует каждый мой шаг.

- You're in denial. / Ты не хочешь этого признавать.

H: - Right. I never had an infarction in my leg. No dead muscle, no nerve damage. Doesn't even hurt, it kinda tickles. And chicks dig this [поднимает трость и показывает на неe] better than a puppy. / Ты права, у меня никогда не было инфаркта в ноге, не было мертвой мышцы, не было повреждения нервов, даже не было боли, вообще-то немного щекотно, а девушкам вот это нравится. Лучше, чем щенок (House M.D. Detox).

Время от времени доктор меняет трость на коллекционную, сделанную на заказ из до- 


\section{МАТЕРИАЛЫ И СООБЩЕНИЯ}

рогих материалов или вовсе на иные предметы быта, которые могут быть применимы в этой роли:

(27) - Got a new cane? / Новая трость?

$\mathrm{H}$ :- Yeah. Guy in the store said it was slimming. Vertical stripe. / Да. Парень в магазине сказал, что она меня стройнит. Вертикальная линия (House M.D. Kids).

Иногда он вымещает на ней свою злость, отождествляя ее с болью и отчаянием, которые переживает:

(28) - You don't think that you have changed in the last few years? / Разве ты не считаешь, что ты изменился за последние несколько лет.

$\mathrm{H}$ : - Of course I have. I've gotten older my hairs got thinner. / Конечно, я изменился. Я стал старше, волос на голове стало меньше.

$\mathrm{H}$ : - You are not just a regular guy who is getting older. You are miserable and you're afraid to face yourself. / Ты не просто обычный малый, который стал старше. Ты жалок, ты боишься признаться себе.

[Сильно ударяет тростью по столу.] менился!

H: - Of course I've changed! / Конечно, я из-

- And everything is the leg? / И все из-за ноги? (House M.D. Detox).

Шон Мерфи («Good doctor») - хирург в одной из американских больниц, страдающий аутизмом. Вещественным идентификатором этой ОРЛ является маленький игрушечный скальпель, подаренный ему его братом, когда они были детьми. Шон всегда носит этот скальпель в кармане, завернув его в платок. Данный идентификатор аккумулирует всю историю жизни персонажа. Когда Шон был маленьким, он сталкивался с семейным насилием, поскольку его отец много пил и открыто демонстрировал ненависть к своему ребенку. Шон и его брат сбегают из дома и становятся беспризорниками, ночуя в заброшенных автомобилях и побираясь. Однажды его брат подарил ему этот скальпель. Вскоре брат Шона погиб, неудачно упав с высоты. Для Шона этот скальпель - единственная вещественная память о брате, символ ушедшего спокойствия и любви. Поэтому в сложных жизненных ситуациях, требующих от Шона предельной концентрации, он достает из кармана этот скальпель и начинает играть с ним.
Примечателен эпизод, когда Шон Мерфи потерял свои игрушечный скальпель и не мог сконцентрироваться ни на одной задаче: он пытался написать химическую формулу на доске, у него не получалось этого сделать, тогда он достал платок, но, не найдя в нем скальпеля, положил платок обратно, вынул все вещи из рюкзака, судорожно пытаясь найти скальпель:

(29) - Shon, I have an inoperable glioma, okay? / Шон, у меня неоперабельная глиома, понимаешь?

[Молчание. Шон достает платок и держит его, глазами пытаясь найти свой скальпель.]

- I think, you should go back to work, yeah? / Думаю, тебе пора вернуться к работе.

[Шон убегает.]

$<\ldots>$

[В кабинете Глассмана Шон прощупывает все кресла.]

- Shon! / Шон!

SH: - I left my scalpel here today. / Я оставил здесь свой скальпель.

$\mathrm{SH}$ [радостно взбегает в кабинет Глассмана]: - He was there all along. / Он все время был на месте (Good Doctor. More).

Важнейшей речевой деталью становится местоимение $h e$, которое использует Шон, говоря о скальпеле (в английском языке he соотносится только с одушевленными существительными).

В качестве вещественных идентификаторов разнообразные предметы быта использованы и в других сериалах, главными персонажами которых являются одаренные речевые личности: Патрик Джейн («Mentalist»), консультант ФБР, всегда лежит на коричневом кожаном диване, размышляя о деле и пытаясь решить головоломку; Фрэнк Андервуд («House of Cards»), конгрессмен, затем 46-й президент США, всегда носит перстень, напоминающий ему об отце, с которым у Фрэнка не сложились отношения; Рэббит («8 Mile»), начинающий рэпер из Детройта, постоянно слушает музыку на своем плеере и записывает в блокнот свои песни.

Вещественные и речевые идентификаторы имеют двойную природу: основное мотивированное значение, которое формируется в соответствии с целью использования того или иного предмета, и немотивированное значение, которое передает информацию об одной из характерных черт хозяина вещи при упоминании о ней 
в коммуникации персонажей. Вещественные и речевые идентификаторы имеют одинаковые функции: аккумулирующую и мнемоническую. Аккумулирующая функция у вещественных идентификаторов выражена сильнее, поскольку эти элементы более символичны.

\section{Заключение}

Наше исследование показало, что повторяющиеся элементы, возникающие в речи одаренной речевой личности, выступают важными деталями ее коммуникативного поведения. В качестве таких деталей могут использоваться слова или словосочетания (речевые идентификаторы), а также элементы костюма, автомобили, бытовые предметы (вещественные идентификаторы). Функциями идентификаторов являются аккумулирующая и мнемоническая. Будучи деталью, идентификаторы концентрируют в себе отличительные черты одаренной речевой личности. Посредством речевых и вещественных идентификаторов одаренная речевая личность транслирует свое подсознательное, раскрываясь перед зрителем и демонстрируя истинную природу своего характера. Многократно повторяясь в речи, идентификатор становится лейтмотивом коммуникативного поведения одаренной речевой личности, образуя у зрителя ассоциативные связи с героем.

Результаты данного исследования позволяют рассматривать идентификатор в качестве основного структурного элемента при создании любого персонажа в художественном произведении, а в дальнейшем позволят характеризовать коммуникативное поведение и языковой портрет любой личности.

\section{ПРИМЕЧАНИЕ}

${ }^{1}$ CM.: 8 Mile. Directed by Curtis Hanson. The USA, 2002.

Amadeus. Directed by Miloš Forman. The USA, 1984.

Californication. The USA. Ep. 84., 2007-2014.

Columbo. Etude in Black. The USA, 1972; Columbo. The Greenhouse Jungle. The USA, 1972; Columbo. The Most Crucial Game. The USA, 1972.

Dexter. An Inconvenient Lie. The USA, 2007; Dexter. The Dark Defender. The USA, 2007; Dexter. Truth to Be Told. The USA, 2006.
Elementary. The USA, 2012-2019.

Fringe. The USA, 2008-2013.

Good Doctor. More. The USA, 2018.

Good, Will Hunting. Directed by Gus Van Sant. The USA, 1997.

Hannibal. Amuse-Bouche. The USA, 2013; Hannibal. Aperitif. The USA, 2013; Hannibal. Sakizuki. The USA, 2014.

House M.D. Acceptance. The USA, 2005; House M.D. Autopsy. The USA, 2005; House M.D. Daddy's Boy. The USA, 2005; House M.D. Detox. The USA, 2005; House M.D. Forever. The USA, 2006; House M.D. Honeymoon. The USA, 2005; House M.D. Hunting. The USA, 2005; House M.D. It's a Wonderful Life. The USA, 2008; House M.D. Kids. The USA, 2005; House M.D. No Reason. The USA, 2006; House M.D. Spin. The USA, 2005; House M.D. Sports Medicine. The USA, 2005.

House of Cards. The USA, 2013-2018.

Lie to Me. The USA, 2009-2011.

Luther. The UK. Ep. 20, 2010-2019.

Mentalist. The USA, 2008-2015

Perception. The USA. Ep. 39, 2012-2015.

Sherlock. The Empty Hearse. The UK, 2014; Sherlock. The Hounds of Baskerville. The UK, 2012; Sherlock. The Lying Detective. The UK, 2017; Sherlock. The Sign of Three. The UK, 2014; Sherlock. The Six Thatchers. The UK, 2017.

Supernatural. The USA. Ep. 307, 2005-2019.

The Lincoln Lawyer. Directed by Brad Furman, The USA, 2011.

\section{СПИСОК ЛИТЕРАТУРЫ}

Добин Е. С., 1981. Сюжет и действительность. Искусство детали. Л. : Сов. писатель. 432 с.

Илюхин Н. И., 2015. Комплексив как средство демонстрации умственных способностей одаренной личности // Научный вестник Воронежского государственного архитектурно-строительного университета. Серия «Лингвистика и межкультурная коммуникация». Вып. 2 (16). С. 108-115.

Илюхин Н. И., Максимова С. Ю., Мацюпа К. В., 2018. Особенности комплексива на материале англоязычных кинофильмов // Филологические науки. Вопросы теории и практики. № 8 (86), ч. 2. С. 337-341.

Караулов Ю. Н., 2010. Русский язык и языковая личность. Изд. 7-е. М. : Изд-во ЛКИ. 264 с.

Киреева 3. А., 2014. Проявление особенностей психики человека в его речи // Вестник Костромского государственного университета им. Н.А. Некрасова. Т. 20, № 3. С. 41-44.

Красных В. В., 2003. «Свой» среди «чужих»: миф или реальность? М. : Гнозис. 375 с. 
Крейдлин Г. Е., 2002. Невербальная семиотика. М. : Новое лит. обозрение. $581 \mathrm{c.}$

Митта А., 1999. Кино по Эйзенштейну, Чехову, Шекспиру, Куросаве, Феллини, Хичкоку, Тарковскому. М. : Подкова. 480 с.

Слышкин Г. Г., Ефремова М. А., 2004. Кинотекст (опыт лингвокультурологического анализа). М. : Водолей Publishers. 153 c.

Соссюр Ф. де, 1999. Курс общей лингвистики / под общ. ред. М. Э. Рут. Екатеринбург : Изд-во Урал. ун-та. $432 \mathrm{c.}$

Страхов И. В., 1998. Психология литературного творчества (Л.Н. Толстой как психолог). М. : ИПП ; Воронеж : НПО МОДЭК. 384 с.

Щирова И. А., 2003. Психологический текст: деталь и образ. СПб. : Изд-во СПбГУ. 120 с.

Эпштейн М., 1987. Конфликт // Литературный энциклопедический словарь / под общ. ред. В. М. Кожевникова, П. А. Николаева. М. : Сов. энцикл. С. 165-166.

Kaufman S. B., Deyoung C. G., Reis D. L., Gray J. R., 2011. General Intelligence Predicts Reasoning Ability even for Evolutionarily Familiar Content // Intelligence. Vol. 39. P. 311-322.

Keri S., 2009. Genes for Psychosis and Creativity: A Promoter Polymorphism of the Neuregulin 1 Gene is Related to Creativity in People with High Intellectual Achievement // Psychological Science. Vol. 20, iss. 9. P. 1070-1073.

Kyaga S., Lichtenstein P., Boman M., Hultman Ch., Lengström N., Landén M., 2011. Creativity and Mental Disorder: Family Study of 300000 People with Severe Mental Disorder // The British Journal of Psychiatry. Vol. 199, iss. 5. P. 373-379.

Mayer R. E., 1999. Fifty Year of Creativity Research // Handbook of creativity / ed. by R. J. Sternbeg. Cambridge : University Press. P. 449-460.

Shaner A., Miller G. F., Mintz J., 2004. Schizophrenia as One Extreme of a Sexually Selected Fitness Indicator // Schizophrenia Research. Vol. 70, iss. 1. P. 101-109.

Zeng L., Proctor R. W., Salvendy G., 2011. Can Traditional Divergent Thinking Tests be Trusted in Measuring and Predicting Real-World Creativity? // Creativity Research Journal. Vol. 23, iss. 1. P. 24-37.

\section{REFERENCES}

Dobin E.S., 1981. Syuzhet i deystvitelnost. Iskusstvo detali [Plot and Reality. Art of a Detail]. Leningrad, Sovetskiy pisatel Publ. 432 p.

Ilyukhin N.I., 2015. Kompleksiv kak sredstvo demonstratsii umstvennykh sposobnostey odarennoy lichnosti [Komplexiv as an Instrument of Mental Capacity Demonstration of a Gifted Person]. Nauchnyy vestnik Voronezhskogo gosudarstvennogo arkhitekturno-stroitelnogo universiteta. Seriya "Lingvistika $i$ mezhkulturnaya kommunikatsiya» [Russian Journal of Building Construction and Architecture. Series "Linguistics and Intercultural Communication”], iss. 2 (16), pp. 108-115.

Ilyukhin N.I., Maksimova S.Yu., Matsyupa K.V., 2018. Osobennosti kompleksiva na materiale angloyazychnykh kinofilmov [Pecularities of Complexive Functioning by the Material of English-Language Films]. Filologicheskie nauki. Voprosy teorii i praktiki [Philological Sciences. Issues of Theory and Practice], no. 8 (86), part 2, pp. 337-341.

Karaulov Yu.N., 2010. Russkiy yazyk i yazykovaya lichnost [Russian Language and Linguistic Persona]. Moscow, Izd-vo LKI. 264 p.

Kireeva Z.A., 2014. Proyavlenie osobennostey psikhiki cheloveka $v$ ego rechi [Manifestation of the Phychological Peculiarities in the Speech of a Person]. Vestnik Kostromskogo gosudarstvennogo universiteta im. N.A. Nekrasova [Vestnik of Kostroma State University], vol. 20, no. 3, pp. 41-44.

Krasnykh V.V., 2003. «Svoy» sredi «chuzhikh»: mifili realnost? ["At Home Among Strangers": Myth or Reality?]. Moscow, Gnozis Publ. 375 p.

Kreydlin G.E., 2002. Neverbalnaya semiotika [NonVerbal Semiotics]. Moscow, Novoe literaturnoe obozrenie Publ. $581 \mathrm{p}$.

Mitta A., 1999. Kino po Eyzenshteynu, Chekhovu, Shekspiru, Kurosave, Fellini, Khichkoku, Tarkovskomu [Cinema by Eisenstein, Chekhov, Shakespeare, Kurosawa, Fellini, Hitchcock, Tarkovsky]. Moscow, Podkova Publ. 480 p.

Slyshkin G.G., Efremova M.A., 2004. Kinotekst (opyt lingvokulturologicheskogo analiza) [Film-Text (The Experience of Lingvoculturological Analysis]). Moscow, Vodoley Publ. 153 p.

Sossyur F. de., 1999. Kurs obshchey lingvistiki [Course in General Linguistics]. Yekaterinburg, Izd-vo Uralskogo universiteta. $432 \mathrm{p}$.

Strakhov I.V., 1998. Psikhologiya literaturnogo tvorchestva (L.N. Tolstoy kak psikholog) [Psychology of Creative Writing (Leo Tolstoy as a Psychologist)]. Moscow, IPP Publ.; Voronezh, NPO MODEK Publ. 384 p.

Shchirova I.A., 2003. Psikhologicheskiy tekst: detal $i$ obraz [Psychological Text: Detail and Image]. Saint Petersburg, Izd-vo SPbGU. 120 p.

Epshteyn M., 1987. Konflikt [Conflict]. Literaturnyy entsiklopedicheskiy slovar [Literary Encyclopedic Dictionary.]. Moscow, Sovetskaya entsiklopediya Publ., pp. 165-166. 
Н.И. Илюхин, С.Ю. Максимова, К.В. Мащюпа. Идентификаторы как средство формирования образа ОРЛ

Kaufman S.B., Deyoung C.G., Reis D.L., Gray J.R., 2011. General Intelligence Predicts Reasoning Ability Even for Evolutionarily Familiar Content. Intelligence, vol. 39, pp. 311-322.

Keri S., 2009. Genes for Psychosis and Creativity: A Promoter Polymorphism of the Neuregulin 1 Gene Is Related to Creativity in People with High Intellectual Achievement. Psychological Science, vol. 20, iss. 9, pp. 1070-1073.

Kyaga S., Lichtenstein P., Boman M., Hultman Ch., Lengström N., Landén M., 2011. Creativity and Mental Disorder: Family Study of 300000 People with Severe Mental Disorder. The
British Journal of Psychiatry, vol. 199, iss. 5, pp. 373-379.

Mayer R.E., 1999. Fifty Year of Creativity Research. Sternbeg R.J., ed. Handbook of Creativity. Cambridge, University Press, pp. 449-460.

Shaner A., Miller G.F., Mintz J., 2004. Schizophrenia as One Extreme of a Sexually Selected Fitness Indicator. Schizophrenia Research, vol. 70, iss. 1, pp. 101-109.

Zeng L., Proctor R.W., Salvendy G., 2011. Can Traditional Divergent Thinking Tests Be Trusted in Measuring and Predicting Real-World Creativity? Creativity Research Journal, vol. 23, iss. 1, pp. 24-37.

\section{Information about the Authors}

Nikita I. Ilyukhin, Candidate of Sciences (Philology), Associate Professor, Department of English Language, Saratov State Academy of Law, Chernyshevskogo St., 104, 410028 Saratov, Russia, tringla@mail.ru, https://orcid.org/0000-0002-8890-093X

Svetlana Yu. Maksimova, Candidate of Sciences (Philology), Associate Professor, Department of English Language, Saratov State Academy of Law, Chernyshevskogo St., 104, 410028 Saratov, Russia, svetlana_maksimova2010@mail.ru,https://orcid.org/0000-0003-4277-8446

Kseniya V. Matsyupa, Candidate of Sciences (Philology), Associate Professor, Department of English Language, Saratov State Academy of Law, Chernyshevskogo St., 104, 410028 Saratov, Russia, kseniashido@mail.ru, https://orcid.org/0000-0002-6388-5120

\section{Информация об авторах}

Никита Игоревич Илюхин, кандидат филологических наук, доцент кафедры английского языка, Саратовская государственная юридическая академия, ул. Чернышевского, 104, 410028 г. Саратов, Россия, tringla@mail.ru, https://orcid.org/0000-0002-8890-093X

Светлана Юрьевна Максимова, кандидат филологических наук, доцент кафедры английского языка, Саратовская государственная юридическая академия, ул. Чернышевского, 104, 410028 г. Саратов, Россия, svetlana_maksimova2010@mail.ru, https://orcid.org/0000-0003-4277-8446

Ксения Владимировна Мацюпа, кандидат филологических наук, доцент кафедры английского языка, Саратовская государственная юридическая академия, ул. Чернышевского, 104, 410028 г. Саратов, Россия, kseniashido@mail.ru, https://orcid.org/0000-0002-6388-5120 